\title{
P504S expressing circulating prostate cells as a marker for prostate cancer
}

\author{
NIGEL P. MURRAY ${ }^{1-3}$, GLORIA M. CALAF ${ }^{4,5}$, LEONARDO BADINEZ ${ }^{6,7}$, RICARDO DUEÑAS $^{8}$, \\ ORLANDO BADINEZ ${ }^{7}$, NELSON ORELLANA ${ }^{8}$, EDUARDO REYES $^{9}$ and CINTHIA FUENTEALBA ${ }^{9}$ \\ ${ }^{1}$ Subdivisión de Hematología, Hospital de Carabineros de Chile; ${ }^{2}$ Instituto de Bio-Oncología; ${ }^{3}$ Facultad de Medicina, \\ Universidad Mayor, Santiago; ${ }^{4}$ Instituto de Alta Investigación, Universidad de Tarapacá, Arica, Chile; ${ }^{5}$ Center for \\ Radiological Research, Columbia University, New York, NY, USA; ${ }^{6}$ Departamento de Radioterapia, Fundación \\ Arturo López Pérez; ${ }^{7}$ Instituto Radio-Oncológico Santiago; ${ }^{8}$ División de Urología, Hospital de Carabineros \\ de Chile; ${ }^{9}$ Training Fellowship Urology, Universidad de Santiago, Santiago, Chile
}

Received December 21, 2009; Accepted April 12, 2010

DOI: $10.3892 /$ or_00000908

\begin{abstract}
Prostate cancer is the most commonly diagnosed cancer in men and the second leading cause of cancer deaths. The serum prostate specific antigen (PSA) is the only biomarker routinely used in screening. The aim of this study was to develop a system to test the presence of circulating prostate cells in men without a diagnosis of prostate cancer in relation with age, serum PSA levels and prostate biopsy by determining the co-expression of several markers such as CD82, HER-2 and matrix metalloproteinase 2 (MMP-2). For this purpose mononuclear cells were separated from blood using differential centrifugation and then prostate cells were identified by using standard immunocytochemical method. Results indicated that among 409 men screened for prostate cancer $16.6 \%$ were positive for circulating prostate cells. Cells were positive for MMP-2 and HER-2 in 100 and $14.3 \%$ of cases, respectively, without an association with age or PSA levels. However, CD82 protein expression was associated with older age and low grade tumors. It can be concluded that the study of circulating prostate cells with various markers could be a useful complementary screening test for prostate cancer in men with increased PSA level.
\end{abstract}

\section{Introduction}

Prostate cancer is the most commonly diagnosed cancer in men and the second leading cause of cancer deaths in Chilean males (1). The controversy surrounding prostate cancer

Correspondence to: Dr Nigel P. Murray, Subdivisión de Hematología, Hospital de Carabineros, Simón Bolívar 2200, Ñuñoa, Santiago, Chile

E-mail: nigelpetermurray@gmail.com

Key words: prostate cancer, disseminated tumor cells, cancer detection, prostate specific antigen, P504S, matrix metalloproteinase 2 screening has prompted many medical organizations to develop guidelines. The serum prostate specific antigen (PSA) is the only biomarker routinely used in screening although highly specific for the prostate an elevated level can be found in benign conditions $(2,3)$. The American Cancer Society and American Urological Association advise men to obtain an annual digital rectal examination (DRE) and serum prostate specific antigen (PSA) test beginning at the age of 50. With the use of screening there has been a $75 \%$ decrease in the rate of metastatic disease at the time of diagnosis between 1992 and 2002, a migration towards earlier stage disease with 70 $80 \%$ of cases being organ confined and therefore potentially curable (4). Total serum PSA is currently used for prostate cancer screening, a level above $4 \mathrm{ng} / \mathrm{ml}$ is associated with an increased risk of detecting prostate cancer, nearly $70 \%$ of cancer cases can be detected with a PSA cut-off level of $4 \mathrm{ng}$ / $\mathrm{ml}$ (5). The use of PSA alone can provide a diagnostic lead time of between 5-10 years compared with DRE, with more than $90 \%$ of these cancers being biologically significant based on tumor volume and grade criteria (6). Although a PSA level of $4 \mathrm{ng} / \mathrm{ml}$ is used as a cut-off point, $22 \%$ of men with a PSA level of between 2.5 and $4.0 \mathrm{ng} / \mathrm{ml}$ have been shown to have clinically significant, organ confined prostate cancer (7-9) The Prostate Cancer Prevention Trial has shown that $15 \%$ of men with a normal DRE and PSA $<4 \mathrm{ng} / \mathrm{ml}$ had cancer diagnosed on biopsy and a 3-fold increase in cancer risk within 10-25 years if the PSA was greater than the median for the patient's age group $(10,11)$. In addition PSA levels can be affected by prostatitis, prostate manipulation as well as medications such as finisteride and herbal supplements such as saw palmetto that might result in unreliable cancer detection. The early spread of cancer cells via the circulation represents one of the failures of cancer treatment, in prostate cancer there is at least one subpopulation of cancer cells that disseminate early to the neurovascular structures and then to the circulation (12). These cells can not be detected by conventional means, but can be detected in blood samples using immunocytochemistry. In men with prostate cancer their presence is associated with stage, Gleason score, disease activity and prognosis (13-16). The detection of CPCs could 
be useful as a complementary screening test for prostate cancer, in that there is not a threshold limit and in CPCnegative men unnecessary biopsies might be avoided.

The $\alpha$-methylacyl-CoA racemase (P504S) protein expression is not expressed in benign prostate tissue as shown in a study of 761 cases where it was analyzed in normal tissues and various malignant neoplasms (17). It is not prostate specific, being found in the cellular component of blood. It has been shown that circulating prostate cells detected in men with prostate cancer expressed P504S (18). Therefore the use of double immunolabelling of anti-PSA and antiP504S could identify malignant circulating prostate cells. It is possible to detect circulating prostate cells positive for P504S in apparently healthy men and this could be used as a complementary screening test for prostate cancer.

Further sub-classification of these cells could provide additional clinically useful information. Studies of prostatectomy samples in cancer patients have shown that CD82 protein expression is lost in high grade cancer (19), the expression of HER-2 in bone marrow micrometastasis and CPCs is associated with androgen independence $(20,21)$ and MMP-2 protein expression is an important factor in metastasis and prognosis (22). Here it is presented a prospective study where P504S protein expression in positive CPCs is analyzed and the association with age, serum PSA levels and prostate biopsy results of men without evidence of prostate cancer attending the Hospital de Carabineros de Chile and Instituto Nacional de Geriatría, Santiago, Chile. Positive samples were further sub-classified for CD82, HER-2 and MMP-2 expression.

\section{Materials and methods}

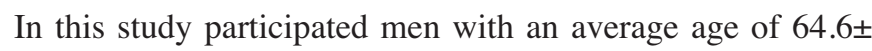
SD 9.9 years, without a history of prostate cancer, prostatectomy or receiving finisteride and attending the Hospital de Carabineros de Chile, Instituto Nacional de Geriatría and Institute of Bio-Oncología, Santiago, Chile. The criteria for prostate biopsy were: serum PSA $\geq 4 \mathrm{ng} / \mathrm{ml}$, abnormal digital rectal examination, annual PSA velocity $\geq 0.75 \mathrm{ng} / \mathrm{ml} /$ year. Thirty women were included as negative controls. After written informed consent, details of age and family history were considered. A 4-ml blood sample for serum PSA was taken by using a 21-G needle collected into EDTA (BeckinsonVacutainer ${ }^{\circledR}$ ) for circulating prostate cell detection. Each sample was coded with a serial number and the cytologist was blinded to patient and biopsy details. Mononuclear cells were separated within $6 \mathrm{~h}$ of obtaining the sample, using gel differential centrifugation at room temperature (Histopaque 1.077, Sigma-Aldrich) according to the manufacture's instructions. The cells were re-suspended in $100 \mu \mathrm{l}$ of autologous plasma and $25 \mu 1$ aliquots of cell suspension used to prepare slides (sialinized Dako, USA) dried in air for $24 \mathrm{~h}$ and fixed using a solution of $70 \%$ ethanol, $5 \%$ formaldehyde and $25 \%$ phosphate buffered saline (PBS) pH 7.4 (Dako) for $5 \mathrm{~min}$ and washed twice with PBS. Slides were processed without $1 \mathrm{~h}$ of fixation and incubated with anti-PSA clone 28A4 (Novocastra Laboratory, UK) in a concentration of $2.5 \mu \mathrm{g} / \mathrm{ml}$ for $1 \mathrm{~h}$ at room temperature. CPCs were identified using an alkaline phosphatase (AP)-antialkaline phosphatase system (LSAB2, Dako) with neo-fuschin as the chromogen and levisamole as an endogenous AP inhibitor according to manufacturer's instructions. Identification of circulating prostate cells (PSA positive cells) was according to the criteria of Ishage (23). A malignant CPC was defined by the morphology of a nucleated cell and staining positive for PSA. Positive samples underwent a second stage, for each patient and one slide was sub-classified for each marker after antigen blocking. Endogenous peroxidase inhibitor solution (Dako) was used according to manufacturer's instructions. Cells expressing CD82, HER-2 and MMP-2 were identified using a peroxidase-based system (LSAB2, Dako) with Vector VIP (Vector, USA) as a chromogen. The anti-CD82 clone 5B5 (Novocastra, UK) was used in a dilution of 1:50, with an incubation at room temperature for $1 \mathrm{~h}$. Positive and negative controls were used. The expression of CD82 was classified according the following semi-quantative scale: 0 , no expression; $1+$, part of the membrane positive for CD82; $2+$, membrane weakly positive; and $3+$, membrane strongly positive. A score of $2+$ and $3+$ in $>10 \%$ of PSA staining cells was considered to be positive. The anti-HER-2 (HercepTest) was used according to manufacturer's instructions and FDA recommendations, a score of $2+$ and $3+$ in $>10 \%$ of PSA staining cells was considered to be positive, according to the criteria used (24). The anti-MMP-2 clone 1B4 (Novacastra) was classified as $0,1-10,11-50$ and $>50 \%$ of cells PSA positive co-expressing MMP-2 and each cell classified semiquantitatively as $0,1+, 2+$ and $3+$ intensity as defined by Trudel et al (25).

The results for the prostate biopsy were obtained from the pathology report, standard hematoxylin-eosin staining was used, and the results recorded as positive or negative for prostate cancer, and the Gleason score noted. Clinical staging was obtained from the case notes. Statistical analysis: descriptive analysis was used for demographic variables, the Student's t-test for differences in age, ANOVA for differences in serum PSA and $\chi^{2}$ for differences in the frequency of subgroups, all tests were two-tailed. An $\alpha$ error of $0.05, \beta$ error of 0.20 and $p<0.05$ was considered as statistically significant.

\section{Results}

Table I shows the frequency of CPCs according to age (Table IA) prostate specific antigen (PSA) (Table IB), and prostate biopsy (Table IC). Table IA indicates that the frequency of CPC detection increased in number from $<55$ to $56-65,66-75$ and 76 years of age in $9.9,15.3,18.6$ and $21.5 \%$, respectively. Men screened for prostate cancer had an average age of $64.6 \pm$ SD 9.9 years and an average PSA of $2.85 \mathrm{ng} / \mathrm{ml}$ that ranged from 0.03 to $44.6 \mathrm{ng} / \mathrm{ml}$. Among them, $16.6 \%$ were positive for CPCs with an average age of $65.9 \pm$ SD 10.2 years and an average serum PSA of $6.06 \mathrm{ng} /$ $\mathrm{ml} \pm \mathrm{SD} 5.64 \mathrm{ng} / \mathrm{ml}$. Men negative for CPCs had a similar average age $64.4 \pm$ SD 7.8 years $(\mathrm{p}=0.27$, two-tailed $\mathrm{t}$-test) but a significantly lower average serum PSA $2.33 \pm$ SD $2.30 \mathrm{ng} /$ $\mathrm{ml}(\mathrm{p}<0.00026$, two-tailed t-test). There was no significant differences between groups in relation with age, but the increasing proportion of positive cases with each age group reached significance $\left(\mathrm{p}<0.034, \chi^{2}\right.$ for trends). The number of positive CPCs per $\mathrm{ml}$ of blood varied between 1 and $11 / \mathrm{ml}$ 
Table I. Frequency of circulating prostate cell (CPC) according to A, age; B, prostate specific antigen (PSA); C, prostate biopsy; D, stage; E, age and serum PSA.

\begin{tabular}{|c|c|c|c|c|c|}
\hline A. Age (years) & $<55$ & $56-65$ & $66-75$ & $\geq 76$ & Total \\
\hline No. of cells $/ \mathrm{ml}$ blood & $4.4 \pm 2.0$ & $4.8 \pm 4.7$ & $3.8 \pm 3.2$ & $5.4 \pm 4.2$ & \\
\hline Total no. of patients positive & 7 & 23 & 23 & 14 & 68 \\
\hline Total patients & 71 & 150 & 124 & 65 & 409 \\
\hline B. PSA (ng/ml) & $<2.0$ & $2.0-4$ & $>4.0-10.0$ & $>10.0$ & Total \\
\hline No. of cells $/ \mathrm{ml}$ blood & $3.2 \pm 1.9$ & $2.1 \pm 0.9$ & $5.1 \pm 3.0$ & $9.7 \pm 8.3$ & \\
\hline Total no. of patients positive & 11 & 16 & 31 & 10 & 68 \\
\hline Total patients & 215 & 88 & 82 & 24 & 409 \\
\hline C. Prostate biopsy & \multicolumn{2}{|c|}{ Positive biopsy (\%) } & \multicolumn{2}{|c|}{ Negative biopsy (\%) } & Total $(\%)$ \\
\hline $\mathrm{CPC}(+)$ & \multicolumn{2}{|c|}{$24(85.7)$} & \multicolumn{2}{|c|}{$7(8.2)$} & $31(27.4)$ \\
\hline CPC (-) & \multicolumn{2}{|c|}{$4(14.3)$} & \multicolumn{2}{|c|}{$78(91.8)$} & $82(72.6)$ \\
\hline Total no. of patients & \multicolumn{2}{|c|}{28} & \multicolumn{2}{|l|}{85} & 113 \\
\hline
\end{tabular}

D. Sub-classification of CPCs in patients with a positive biopsy $(n=24)$.

\begin{tabular}{lccc}
\hline Stage & $\begin{array}{c}\text { CD82 } \\
\text { Positive/Negative }\end{array}$ & $\begin{array}{c}\text { HER-2 } \\
\text { Positive/Negative }\end{array}$ & $\begin{array}{c}\text { MMP-2 } \\
\text { Positive/Negative }\end{array}$ \\
\hline Gleason $4+5$ & $5 / 5$ & $3 / 7$ & $10 / 0$ \\
Gleason $\geq 6$ & $0 / 14$ & $2 / 12$ & $14 / 0$ \\
Stage 2 & $4 / 12$ & $3 / 13$ & $16 / 0$ \\
Stage 3 & $2 / 6$ & $2 / 6$ & $8 / 0$ \\
\hline
\end{tabular}

E. Sub-classification of CPCs according to CD82 and HER-2.

\begin{tabular}{lcccr}
\hline & \multicolumn{2}{c}{ CD82 } & & HER-2 \\
\cline { 2 - 4 } Age and serum & Positive & Negative & Positive & Negative \\
\hline Total no. of patients & 22 & 46 & 8 & 60 \\
Age & $71.3 \pm 9.8$ & $62.9 \pm 8.4$ & $66.4 \pm 10.3$ & $67.1 \pm 9.2$ \\
PSA & $8.09 \pm 8.00$ & $5.76 \pm 5.60$ & $6.05 \pm 5.90$ & $10.0 \pm 9.8$ \\
\hline
\end{tabular}

and there was no relationship between the number of cells and age, but men with higher serum PSA values had higher numbers of CPCs $/ \mathrm{ml}$ detected (Table IB). Men with a PSA $<10.0 \mathrm{ng} / \mathrm{ml}$ had a significantly higher number of $\mathrm{CPCs} / \mathrm{ml}$ detected, in comparison with $<2.0 \mathrm{ng} / \mathrm{ml}$ ( $\mathrm{p}<0.02$, two-tailed t-test), $2.0-4.0 \mathrm{ng} / \mathrm{ml}(\mathrm{p}<0.001$, two-tailed t-test) and the $>4.0-10.0 \mathrm{ng} / \mathrm{ml}$ group $(\mathrm{p}<0.016$, two-tailed t-test). Men with a PSA in the range $>4.0-10.0 \mathrm{ng} / \mathrm{ml}$ had a higher cell number than those with a PSA of $2.0-4.0 \mathrm{ng} / \mathrm{ml}(\mathrm{p}<0.0003$, two-tailed $\mathrm{t}$-test), there were no differences between men with a PSA $<2.0 \mathrm{ng} / \mathrm{ml}$ and between $2.0-4.0 \mathrm{ng} / \mathrm{ml}$ or $<2.0 \mathrm{ng} / \mathrm{ml}$ in comparison with the group $4.0-10.0 \mathrm{ng} / \mathrm{ml}$.

There was an association in men with serum PSA and the frequency of positive CPC that increased significantly with increasing serum PSA values, when compared between groups $(p<0.0001)$ (Table IC). It indicated that there was significant difference between $<2.0 \mathrm{ng} / \mathrm{ml}$ in comparison to $2.0-4.0 \mathrm{ng} / \mathrm{ml}(\mathrm{p}<0.0003)$, and $>4.0-10.0 \mathrm{ng} / \mathrm{ml}(\mathrm{p}<0.00001)$ and $>10 \mathrm{ng} / \mathrm{ml}(\mathrm{p}<0.00005)$, as well as $2.0-4.0 \mathrm{ng} / \mathrm{ml}$ in comparison to $>4.0-10.0 \mathrm{ng} / \mathrm{ml}(\mathrm{p}<0.003)$; and in comparison to $>10.0 \mathrm{ng} / \mathrm{ml}(\mathrm{p}<0.05)$. There was no significance in group $>4.0-10.0 \mathrm{ng} / \mathrm{ml} \mathrm{vs} .>10.0 \mathrm{ng} / \mathrm{ml}$ ( $\mathrm{p}=0.09) \mathrm{NS}$ ( $\chi^{2}$ two-tailed). There was a significant association between biopsy results and the presence or absence of positive CPCs $(\mathrm{p}<0.0000001$, two-tailed $\chi^{2}$ ), with a specificity of $91.8 \%(78 / 85)$ and sensitivity of $85.7 \%(24 / 28)$. There was a false positive rate of $7 / 31(22.6 \%)$ as compared with serum PSA of $85 / 113$ $(75.2 \%)\left(\mathrm{p}<0.0001, \chi^{2}\right)$. The false negative rate was $4 / 28$ 

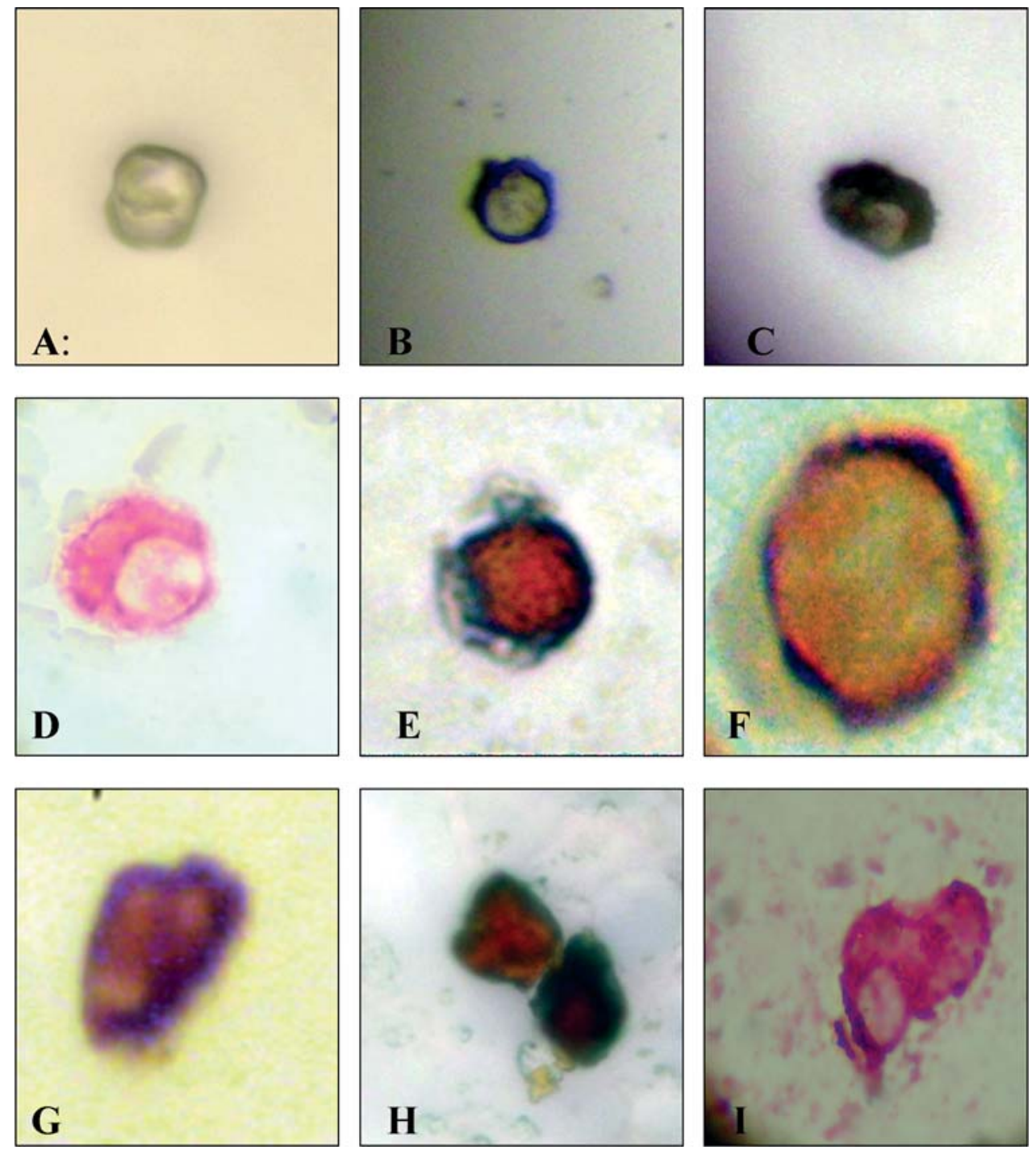

Figure 1. (A) Leucocytes negative for MMP-2; (B) Leucocytes positive for P504S; (C) Leucocytes positive for MMP-2, 3+ positive; (D) Circulating prostate cells negative for HER-2 and CD82; (E) Circulating prostate cells positive for HER-2, 3+ positive; (F) Circulating prostate cells positive for CD82, 2+ positive; (G) Circulating prostate cells positive for P504S; (H) Circulating prostate cells positive for MMP-2 positive; (I) Circulating prostate cells negative for P504S.

(14.3\%) for positive CPCs. Among the 4 patients with negative CPCs for prostate cancer, three of them were Gleason score 4 and 1 was Gleason score 5 with only $5 \%$ positive biopsy sample.

A sub-classification of CPCs was considered as seen in Table I,D and E. All CPCs expressed MMP-2 with an intensity of $2+$ or $3+$. For this reason, the classification of CPCs according to (\%) MMP-2 positivity with age and/or serum PSA was not evaluated. The men 22/68 (32.4\%) that had CD82 positive CPCs had a mean age of $71.3 \pm 9.8$ years vs. $62.9 \pm$ 8.4 years $(\mathrm{p}<0.005$, two-tailed t-test), there was no difference in serum PSA levels $8.09 \mathrm{ng} / \mathrm{ml}$ (range 0.4-44.5 ng/ml) vs. $5.76 \mathrm{ng} / \mathrm{ml}$ (range $0.2-20.5 \mathrm{ng} / \mathrm{ml}$ ) respectively in comparison with CD82 negative men ( $\mathrm{p}=0.26$, two-tailed t-test) (Table I, D). In men CPC positive and a positive prostate biopsy $(n=24)$, CD82 expression was associated with low grade cancer, 5/10 $(50 \%)$ Gleason $4+5$ vs. $0 / 14(0 \%)$ Gleason $\geq 6$ (p<0.006, Fisher two-tailed), but not with clinical stage $4 / 16$ stage 2 vs. $2 / 8$ stage 3 ( $\mathrm{p}=1.0$, Fisher two-tailed) (Table I, E).
Men 8/68 (11.8\%) had CPCs that were HER-2 positive. There was not significant difference in CPCs with positive HER-2 in relation to age ( $\mathrm{p}=0.85$, $\mathrm{t}$-test two-tailed) or serum PSA level ( $\mathrm{p}=0.19$, t-test two-tailed) (Table I, F). In those men with CPCs and with positive prostate cancer biopsy $(n=25)$, there was not an association of HER-2 expression with Gleason score $(\mathrm{p}=0.61$, Fisher two-tailed) or clinical stage $(\mathrm{p}=1.00$, Fisher two-tailed) (Table I, E). Fig. 1 correspond to representative images of cells analyzed in these studies. Fig. 1 correspond to (A) leucocytes negative for MMP-2; (B) leucocytes positive for P504S; (C) leucocytes positive for MMP-2, +3 positive; (D) circulating prostate cells negative for HER-2 and CD82; (E) circulating prostate cells positive for HER-2, $3+$ positive; (F) circulating prostate cells positive for CD82, $2+$ positive; $(\mathrm{G})$ circulating prostate cells positive for P504S; (H) circulating prostate cells positive for MMP-2 positive; (I) circulating prostate cells positive for MMP-2 positive; (J) circulating prostate cells for CD82 positive +3 ; (K) circulating prostate cells negative for P504S. 


\section{Discussion}

The incidence of clinical prostate cancer increases with age, from 0.2 to $0.9 \%$ from 50 - to 80 -year-old men. However, cancer detected as a result of an abnormal DRE or serum PSA may be underestimated. Latent prostate cancer is defined as an asymptomatic cancer detected only at autopsy, published studies have show a much higher incidence of latent cancer than in population studies of clinical cancer (24). Latent cancer is not linearly associated with age; and there is a plateau in the incidence of latent cancer between 60 and 70 years. The frequency of circulating prostate cells showed a similar trend, increasing after 55 years and with a plateau between 60 and 80 years.

The frequency of CPCs significantly increased with serum PSA levels. In men with a serum PSA of $<4.0 \mathrm{mg} / \mathrm{ml}$, it has been shown there is a frequency of prostate cancer of $15.0 \%$; with a serum PSA of $<2.0 \mathrm{ng} / \mathrm{ml}$ the frequency was is $10.8 \%$; with a serum PSA of $2.0-4.0 \mathrm{ng} / \mathrm{ml}$ it fluctuates between 21.0 and $24.5 \%(25,26)$. In comparison the frequency of CPCs was 5.2 and $18.2 \%$ for these two groups. In men with a serum PSA $>4.0 \mathrm{ng} / \mathrm{ml}$ the frequency of cancer detected was between $30-38 \%$ in the range $4.0-10.0 \mathrm{mg} / \mathrm{ml}$ and approximately $50 \%$ in the range $>10.0 \mathrm{ng} / \mathrm{ml} \mathrm{(27)}$. The frequency of CPCs was similar in the range $4.0-10.0 \mathrm{mg} / \mathrm{ml}$, with a detection rate of 39.0 and $38.1 \%$, respectively. The number of $\mathrm{CPCs} / \mathrm{ml}$ blood also increased with serum PSA levels, tumor size could disrupt the architecture of the prostate gland thus allowing more cells to escape or represents tumors that have penetrated the capsule. That there was no such relation with age would suggest that tumor size is a more important cause of hematogenous spread.

There was a significant association with the results of the prostate biopsy. The results showed a sensitivity of $85.7 \%$ and specificity of $91.3 \%$, which suggests that men with an increased serum PSA, but negative for circulating prostate cells might not require biopsy and undergo a period of observation. Men with a normal serum PSA, but positive CPCs should be closely followed up or considered for prostate biopsy. It can be suggested that a further sub-classification of circulating prostate cells could add clinically important information for cancer patients. The expression of MMP-2 in all the CPCs is supporting evidence for its pivotal role in cancer dissemination, allowing early spread of tumor cells. That low grade cancers expressed CD82 while intermediate and high grade cancers were negative for CD82 suggests that CD82 expression in circulating prostate cells could be clinically useful to select these older people for observation status approach rather than early prostate biopsy. The expression of HER-2 is similar to that reported in studies of circulating prostate cells in men with prostate cancer and without androgen blockage (28). Larger studies are needed on these findings to confirm that the detection of CPCs would be clinically important as a complementary test in prostate cancer screening programs.

\section{Acknowledgements}

The support given by Hospital de Carabineros de Chile Research Fund is greatly appreciated. We thank Fondecyt \#1080482.

\section{References}

1. Szot J: Epidemiological analysis of mortality caused by solid tumors in the Metropolitan Region, Chile, 1999. Rev Med Chile 131: 641-649, 2003.

2. Punglia RS, D'Amico AV, Catalona WJ, Roehl KA and Kuntz KM: Impact of age, benign prostatic hyperplasia and cancer on prostate specific antigen levels. Cancer 106: 1507-1513, 2006.

3. Bozeman CB, Carver BS, Eastham JA and Venable DD: Treatment of chronic prostatitis lowers serum prostate specific antigen. J Urol 167: 1723-1726, 2002.

4. Catalona WJ, Smith DS, Ratliff TL and Basler JW: Detection of organ-confined prostate cancer is increased through prostatespecific antigen-based screening. JAMA 270: 948-954, 1993.

5. Gann PH, Hennekens $\mathrm{CH}$ and Stampfer MJ: A prospective evaluation of plasma prostate-specific antigen for detection of prostatic cancer. JAMA 273: 289-294, 1995.

6. Krumholtz JS, Carvalhal GF, Ramos CG, et al: Prostate-specific antigen cut-off of $2.6 \mathrm{ng} / \mathrm{ml}$ for prostate cancer screening is associated with favorable pathologic tumor features. Urology 60: 469-474, 2002.

7. Catalona WJ, Smith DS and Ornstein DK: Prostate cancer detection in men with serum PSA concentrations of 2.6 to $4.0 \mathrm{ng}$ / $\mathrm{ml}$ and benign prostate examination. Enhancement of specificity with free PSA measurements. JAMA 277: 1452-1455, 1997.

8. Horninger W, Berger AP, Rogatsch H, et al: Characteristics of prostate cancers detected at low PSA level. Prostate 58: 232-237, 2004.

9. Thompson IM, Pauler DK, Goodman PJ, et al: Prevalence of prostate cancer among men with a prostate-specific antigen level $\leq 4.0 \mathrm{ng}$ per millimeter. N Eng J Med 350: 2239-2246, 2004.

10. Fang J, Metter EJ, Landis P, Chan DW, Morrell CH and Carter HB: Low level of prostate-specific antigen predict longterm risk of prostate cancer: results from the Baltimore Longitudinal Study on Aging. Urology 58: 411-416, 2001.

11. Loeb S, Roehl KA, Antenor JA, Catalona WJ, Suarez BK and Nadler RB: Baseline prostate-specific antigen compared with median prostate-specific antigen for age group as predictor of prostate cancer risk in men younger than 60 years old. Urology 67: 316-320, 2006.

12. Moreno JG, Croce CM, Fischer R, Monne M, Vihko P, Mulholland SG and Gomella LG: Detection of hematogenous micrometastasis in patients with prostate cancer. Cancer Res 52: 6110-6112, 1992.

13. Moreno JG, Miller MC, Gross S, Allard WJ, Gomella LG and Terstappen LW: Circulating tumor cells predict survival in patients with metastatic prostate cancer. Urology 65: 713-718, 2005.

14. Chen BT, Loberg A, Neeley CK, et al: Preliminary study of immunomagnetic quantification of circulating tumor cells in patients with advanced disease. Urology 65: 616-621, 2005.

15. Wang ZP, Eisenberger MA, Carducci MA, Partin AW, Scher HI and Tsò PO: Identification and characterization of circulating prostate carcinoma cells. Cancer 88: 2787-2795, 2000.

16. Murray NP: El uso de doble-inmumomarcación para detectar células prostáticas en la circulación sanguínea en pacientes con cáncer prostática y las correlaciones con los parámetros clínicos. Rev Chil Urol 71: 135-140, 2006.

17. Jiang Z, Fanger GR, Wodo BA, et al: Expression of alphamethylacyl-CoA racemase (P504S) in various malignant neoplasms and normal tissues: a study of 761 cases. Hum Pathol 34: 792-796, 2003.

18. Murray NP and Badinez L: Las células prostáticas en al circulación sanguínea en pacientes con cáncer prostático expresan la proteína P504S: un estudio utilizando inmunocitoquímica. Rev Chil Urol 73: 54-57, 2008.

19. Bouras T and Frauman AG: Expression of the prostate cancer metastasis suppressor gene KAI1 in primary prostate cancers: a biphasic relationship with tumour grade. J Pathol 188: 382-388, 1999.

20. Murray NP: La expresión de HER-2 en células prostáticas en la circulación sanguínea y el efecto de la supresión androgénica en hombres con cáncer prostático. Rev Chil Urol 72: 190-194, 2007.

21. Murray NP and Badinez L: Expression of HER-2 in disseminated tumor cells in bone marrow of patients with prostate cancer is associated with resistance to androgen blockage but not DES. Urology 72 (Suppl. 5A): S65, 2008. 
22. Ross JS, Kaur P, Sheehan CE, Fisher HA, Kaufman RA Jr and Kallakury BV: Prognostic significance of matrix metalloproteinase 2 and tissue inhibitor of metalloproteinase 2 expression in prostate cancer. Mod Pathol 16: 198-205, 2003.

23. Borgen E, Naume B, Nesland JM, et al: Standardization of the immunocytochemical detection of cancer cells in BM and blood: establishment of objective criteria for the evaluation of immunostained cells. Cytotherapy 5: 377-388, 1999.

24. Osman I, Scher HI, Drobnjak M, et al: HER-2/neu (p185neu) protein expression in the natural or treated history of prostate cancer. Clin Cancer Res 7: 2643-2647, 2001.

25. Trudel D, Fradet Y, Meyer F, Harel F and Têtu B: Significance of MMP-2 expression in prostate cancer: an immunohistochemical study. Cancer Res 63: 8511-8515, 2003
26. British Cancer Registry: Health Ministry United Kingdom, Department of Statistics, London, 2007.

27. Reissigl A, Horninger W, Fink K, Klocker H and Barjch G: Prostate carcinoma screening in the county of Tyrol, Austria: experience and results. Cancer 80: 818-829, 1997.

28. Babaian RJ, Johnson DA, Naccarato W, Ayala A, Bhadkamker VA and Fritsche HA Jr: The incidence of prostate cancer in a screening population with a serum PSA between 2.5 and $4.0 \mathrm{ng} / \mathrm{ml}$. J Urol 165: 757-760, 2001. 